Formatif: Jurnal Ilmiah Pendidikan MIPA

Vol. 8, No. 3, Desember 2018, pp. 159-174

p-ISSN: 2088-351X

e-ISSN: 2502-5457

DOI: http://dx.doi.org/10.30998/formatif.v8i3.2716

\title{
Math Comics, Vectors, and the Strategy of Preview, Question, Read, Reflect, Recite, Review (PQ4R)
}

\author{
Komik Matematika, Materi Vektor, dan Strategi Preview, Question, Read, Reflect, \\ Recite, Review (PQ4R)
}

\author{
Kristina Kurniati \\ STKIP Santu Paulus, Ruteng, NTT \\ Rully Charitas Indra Prahmana (*) \\ Universitas Ahmad Dahlan \\ Alberta Parinters Makur \\ STKIP Santu Paulus, Ruteng, NTT \\ Silfanus Jelatu \\ STKIP Santu Paulus, Ruteng, NTT
}

$\begin{array}{ll} & \\ \text { Received: } & \text { August 4, } 2018 \\ \text { Revised: } & \text { September 29, } 2018 \\ \text { Accepted: } & \text { October } 12018\end{array}$

\begin{abstract}
The study aims to develop a mathematical comic's media of vector material on the subject of vector notation and its operation through the strategy of Preview, Question, Read, Reflect, Recite, Review (PQ4R). Furthermore, the product implemented for senior high school students at SMA N 1 Langke Rembong 2017/2018 academic years to know the quality of the media. The instruments used in this research are mathematical comic evaluation sheet, student response questionnaire, and student achievement mathematics test. The learning aid develops through the development model of ADDIE namely Analysis, Design, Development, Implementation, and Evaluation. The results show that the validity of learning aid with the criteria passes without revision based on the validator assessment of the material, language, and media with the score of 4.00, 4.00, and 3.75 respectively. For the aspect of practicality, the media includes in passing criteria and appropriate to be used without revision based on teacher's assessment of comic mathematics with score 4.47 and student response questionnaire with score 3.64 with criteria well used in the learning process. Lastly, the potential effects of mathematical comics include in the high standards based on student achievement test with the percentage of mastery by $75 \%$.
\end{abstract}

Keywords: math comics, vector, PQ4R strategy

(*) Corresponding Author: $\quad$ rully.indra@mpmat.uad.ac.id

How to Cite: Kurniati, K., Prahmana, R.C.I., Makur, A.P., \& Jelatu, S. (2018). Math comics, vectors, and the strategy of preview, question, read, reflect, recite, review (PQ4R). Formatif: Jurnal Ilmiah Pendidikan MIPA, 8(3), 159-174. http://dx.doi.org/10.30998/formatif.v8i3.2716

\section{PENDAHULUAN}

Mengajar matematika bukanlah hal yang mudah. Berdasarkan pengalaman beberapa guru peraih penghargaan yang ditulis dalam buku Cara-Cara Terbaik Mengajarkan Matematika, 
Formatif: Jurnal Ilmiah Pendidikan MIPA

Vol. 8, No. 3, Desember 2018, pp. 159-174

p-ISSN: 2088-351X

e-ISSN: 2502-5457

DOI: http://dx.doi.org/10.30998/formatif.v8i3.2716

Sharon Andrews dari South Dakota menuliskan, "Tantangan saat mengajar matematika adalah bagaimana berkomunikasi dengan murid, bagaimana membuat mereka mengikuti proses belajar aktif, dan bagaimana konsisten melakukan hal itu" (Stone, 2009). Selanjutnya, Pam Roller (Stone, 2009) dari Galveston Indiana menuliskan, "Saya menemukan bahwa ketika saya sedang mengajar dasar-dasar matematika, murid-murid belajar terbaik ketika guru memilih untuk memadukan kurikulum." Penggunaan strategi yang tepat dalam proses pembelajaran diharapkan dapat memaksimalkan peningkatan kemampuan berpikir tingkat tinggi siswa (Makur, Prahmana, \& Gunur, 2018; Prahmana, 2017).

Berbagai peran guru dalam proses pembelajaran di atas menghadapi berbagai tantangan dalam pengaplikasiannya. Tantangan tersebut muncul dari kondisi sehari-hari yang dapat disaksikan di dalam kelas saat melakukan aktivitas pembelajaran. Namun, beberapa tugas untuk mengatasi masalah tersebut masih bersumber pada guru. Sebagaimana yang diungkapkan Jelatu, dkk. (2018) bahwa guru memiliki peran penting dalam pembelajaran khususnya dalam menciptakan pembelajaran yang berkualitas. Untuk menghidupkan perhatian siswa dalam pembelajaran, guru diharapkan dapat menggunakan model pembelajaran yang bervariasi serta dinamis. Guru matematika memiliki kecenderungan untuk lebih berfokus pada proses pembelajaran yang berorientasi pada buku (textbook oriented) dan membiasakan strategi pembelajaran langsung, memberikan contoh dari masalah dan meminta siswa mengerjakan soal-soal ke dalam buku yang mereka gunakan dalam pembelajaran (Pardimin \& Widodo, 2012).

Mudri (2010) menyatakan bahwa terdapat 10 peran guru yaitu sebagai pendidik, pengajar, pembimbing, pelatih, penasihat, model dan teladan, aktor, emansipator, dan evaluator, guru juga berperan sebagai pendorong kreativitas, yang merupakan hal penting dalam pembelajaran. Guru dituntut untuk mendemonstrasikan dan menunjukkan proses kreativitas tersebut (Hendriana, dkk. 2018). Oleh karena itu, guru diharapkan mampu menjadi fasilitator dalam menumbuhkan kemampuan kreativitas siswa.

Setiap orang dilahirkan di dunia dengan memiliki potensi kreatif. Pada dasarnya, kreativitas dapat diidentifikasi dan dipupuk melalui pendidikan yang tepat (Munandar, 2009). Kreativitas guru dapat berimplikasi pada proses dan hasil pembelajaran. Pembelajaran yang membosankan menyebabkan motivasi belajar rendah yang berpengaruh pada pemahaman konsep yang kurang dan pengetahuan yang mudah dilupakan (Prahmana, 2013; Abdullah, dkk. 2018). Di sisi lain, siswa yang memiliki kreativitas akan mampu mengembangkan penguasaan pengetahuan dan atau konsep dasar sehingga dapat menerapkan ilmunya dalam kehidupan sehari-hari.

Dalam pembelajaran matematika, kreativitas merupakan salah satu hal yang sulit dikembangkan guru. Hal ini, disebabkan oleh berbagai faktor seperti keberagaman kemampuan dan minat siswa untuk mempelajari matematika, maupun keterbatasan waktu serta kemampuan dan suasana hati guru itu sendiri. Berdasarkan konteks pembelajaran matematika yang terjadi di SMA Negeri 1 Langke Rembong, peneliti mengamati dan mengalami beberapa kesulitan dalam mengajar matematika. Saat pembelajaran berlangsung, sering ditemukan beberapa siswa yang sering absen, ada juga siswa yang mengantuk dan tidak memerhatikan penjelasan guru maupun malas membaca buku teks. Siswa bahkan lebih suka membaca buku-buku bergambar non pengetahuan seperti komik.

Menciptakan proses pembelajaran menjadi menyenangkan merupakan salah satu cara yang paling penting untuk mengatasi semuanya itu, sehingga pengalaman belajar menjadi bermakna dan siswa memiliki rasa ingin tahu serta minat yang tinggi akan pelajaran matematika. Selain itu, guru perlu mengubah pilihan media pembelajaran. Hal ini dikarenakan, media yang digunakan guru yaitu media buku teks membosankan dikarenakan oleh kurangnya kreativitas guru dalam mengakomodir dan memfasilitasi pembelajaran. 
Formatif: Jurnal Ilmiah Pendidikan MIPA

Vol. 8, No. 3, Desember 2018, pp. 159-174

p-ISSN: 2088-351X

e-ISSN: 2502-5457

DOI: http://dx.doi.org/10.30998/formatif.v8i3.2716

Kurikulum 2013 (Kurtilas) menjadikan kreativitas sebagai fokus pembelajaran aktif. Guru dituntut untuk dapat mengakomodasi setiap karakteristik siswa dengan berbagai gaya belajar. Hal ini, menjadi salah satu tantangan yang cukup berat bagi seorang guru dengan latar belakang keluarga, budaya, dan pengalaman yang berbeda. Bagi seorang guru matematika, salah satu cerminan kreativitas adalah penggunaan media kreatif yang dapat menunjang kefektifan proses pembelajaran yang berdampak pada hasil belajar siswa yang memuaskan yaitu memenuhi Kriteria Ketuntasan Minimum (KKM) yang ditetapkan sekolah.

Media pembelajaran memudahkan guru dalam proses pembelajaran dan dapat membantu siswa dalam meningkatkan hasil belajar karena media merupakan salah satu faktor yang dapat menimbulkan motivasi dan kegairahan belajar dalam diri siswa. Penggunaan media dapat meningkatkan minat dan motivasi belajar matematika siswa. Rusman (Sinurat, dkk. 2015) menuliskan guru tidak cukup hanya memiliki pengetahuan tentang media pendidikan, tetapi juga harus memiliki keterampilan memilih dan menggunakan serta mengusahakan (membuat ataupun mengembangkan) media itu dengan baik. Jelatu, dkk. (2018) berasumsi bahwa penggunaan media merupakan salah satu kebutuhan penting dalam pembelajaran matematika melalui dinamisme terhadap representasi konsep-konsep sehingga pemahaman siswa terhadap konsep-konsep matematika dapat dioptimalkan dan lebih komprehensif.

Selama proses analisis kebutuhan yang dilakukan di SMA Negeri 1 Langke Rembong peneliti dapat menyimpulkan bahwa dibutuhkan strategi untuk meningkatkan minat dan motivasi belajar matematika sekaligus meningkatkan kemampuan dan prestasi belajar matematika. Strategi ini mengarah pada variasi penggunaan media dan strategi pembelajaran yang dapat mengakomodir semua siswa dengan beragam kemampuan serta beragam cara belajar. Mengingat kecendrungan siswa di SMA Negeri 1 Langke Rembong yang lebih suka membaca buku-buku bergambar non pengetahuan seperti komik, maka memadukan komik ke dalam pembelajaran matematika merupakan hal yang dibutuhkan.

Komik merupakan salah satu media pendidikan. Komik dapat menjadi salah satu media pembelajaran matematika yang dapat dikembangkan guru. Hamida (2012) mendefinisikan komik sebagai media visual konkret yang dapat meningkatkan pemahaman dan daya ingat akan materi pelajaran matematika yang sedang dibahas. Selain itu, komik dilengkapi dengan dialogdialog yang mengandung pesan-pesan tertentu termasuk pesan dan materi pendidikan. Komik dapat menjadi bahan bacaan yang menarik serta dapat mengembangkan kebiasaan membaca.

Hosler \& Boomer (2011) menyatakan bahwa nilai potensial komik dalam pendidikan dan literasi siswa bukanlah konsep baru. Pendidik telah menggunakan komik di kelas selama lebih dari 60 tahun. Guru yang menggunakannya dalam pembelajaran menunjukkan bahwa komik menghasilkan peningkatan minat siswa secara individu dan membuat proses belajar menjadi mudah. Hal senada juga diungkapkan oleh Green dan Myers (2010) yang menyatakan bahwa komik telah digunakan untuk memotivasi anak-anak untuk membaca, melatih siswa dalam seni bahasa dan juga digunakan dalam pendidikan kedokteran dan perawatan pasien.

Yang Gene (Marianthi, dkk. 2016) menyatakan bahwa komik memiliki banyak kekuatan dalam pembelajaran. Kekuatan-kekuatan tersebut di antaranya adalah (1) Memotivasi, karena daya tarik alami manusia ke gambar, maka komik dapat menangkap dan mempertahankan minat pelajar, (2) Visual, gambar dan teks saling menceritakan sebuah kisah. Komik menempatkan wajah manusia pada subjek yang diberikan sehingga menghasilkan hubungan emosional antara siswa dan karakter dari cerita komik, (3) Perantara, komik dapat menjembatani penguasaan konsep yang sulit, memberi pembaca pengalaman dan memperoleh inspirasi serta kepercayaan diri untuk mempelajari teks yang lebih menantang, dan (4) Pengembangan keterampilan berpikir, kemampuan berpikir analitis dan kritis dapat dikembangkan melalui komik.

Pemilihan komik sebagai media pembelajaran matematika didukung oleh kesukaan dan kebiasaan siswa SMA membaca komik. Selain itu, program literasi yang dicanangkan 
Formatif: Jurnal Ilmiah Pendidikan MIPA

Vol. 8, No. 3, Desember 2018, pp. 159-174

p-ISSN: 2088-351X

e-ISSN: 2502-5457

DOI: http://dx.doi.org/10.30998/formatif.v8i3.2716

pemerintah bagi siswa di sekolah dapat ditingkatkan keefektifannya dengan menyediakan bahan bacaan yang menunjang hasil belajar terutama matematika dengan menyajikannya secara menarik melalui komik matematika. Hasil penelitian Rasiman \& Pramasdyahsari (2014) menunjukan bahwa penggunaan media komik dalam pembelajaran matematika dapat menumbuhkembangkan kemampuan berpikir kritis siswa.

Proses analisis kebutuhan menunjukkan bahwa dibutuhkan strategi untuk meningkatkan minat dan motivasi belajar matematika sekaligus meningkatkan kemampuan dan prestasi belajar matematika. Strategi ini mengarah pada variasi penggunaan media dan strategi pembelajaran yang dapat mengakomodir semua siswa dengan beragam kemampuannya. Siswa membutuhkan bahan bacaan untuk meningkatkan pemahamannya akan materi pelajaran yang didukung oleh kebiasaan dan kesukaannya terhadap media komik. Peneliti menemukan banyak siswa mengoleksi komik, mengingat dengan baik jalan ceritanya, dan menghabiskan banyak waktu untuk membaca komik. Oleh karena itu, peneliti berinisiatif membelajarkan matematika dengan media komik. Komik yang dikembangkan memuat konsep-konsep matematika yang memudahkan siswa mengingatnya.

Penggunaan media komik dalam pembelajaran matematika perlu dipadukan dengan strategi pembelajaran yang memberi ruang bagi siswa untuk aktif membaca. Strategi yang dapat digunakan yaitu strategi Preview, Question, Read, Reflect, Recite, Review (PQ4R). Strategi ini dapat memperbaiki kreativitas berpikir siswa dan kualitas pembelajaran. Behzadi, dkk. (2014) menuliskan bahwa salah satu metode belajar dan pembelajaran yang efektif dan berhasil dalam matematika adalah metode yang dikenal dengan PQ4R. Berkaitan dengan jenis-jenis strategi kognitif dan meta-kognitif, Behzadi, dkk. (2014) menyatakan bahwa strategi-strategi ini dapat digunakan untuk mempelajari konsep-konsep matematika dan efekktif dalam meningkatkan prestasi belajar matematika.

Strategi pembelajaran PQ4R merupakan suatu strategi pembelajaran yang dapat membantu siswa untuk mengingat apa yang mereka baca, melatih siswa untuk bertanggung jawab atas materi yang mereka pelajari, dan memberi kesempatan kepada siswa untuk mengembangkan potensi diri dan belajar lebih aktif dan kreatif (Savitri, dkk. 2013). Strategi khusus ini membantu siswa untuk memproses informasi penting dalam waktu yang terbatas. Hal ini, memungkinkan siswa mengarahkan pemikiran mereka ke tugas yang diberikan sebelum menyelesaikan pembelajaran (Kleden, dkk. 2015). Penggunaan strategi ini juga memberi ruang bagi siswa untuk membangun pemahamannya sendiri terhadap konsep-konsep pembelajaran dengan kegiatan membaca intensif. Di dalam belajar matematika, kebiasaan membaca yang baik dapat meningkatkan pengetahuan dan pemahaman pada substansi matematika seperti fakta-fakta dan simbol-simbol matematika.

Strategi ini efektif untuk siswa di tingkat pendidikan yang lebih tinggi karena memungkinkan siswa untuk lebih fokus pada pengumpulan informasi yang berarti dan mereka dapat melibatkan diri dalam menciptakan pertanyaan, menjelaskan, dan menginvestigasi ulang informasi (Ramdiah \& Corebima, 2014). Kesemuanya ini membuat pembelajaran menjadi lebih bermakna karena siswa dapat belajar lebih aktif dengan membangun pemahaman mereka sendiri melalui apa yang mereka baca dengan bantuan media komik. Pembelajaran menjadi lebih menyenangkan namun juga lebih terarah dengan penggunaan strategi PQ4R.

Salah satu materi matematika yang membutuhkan kemampuan membaca adalah vektor. Materi vektor kini dibahas di kelas X matematika peminatan Kurtilas. Menurut analisis peneliti, materi ini diberikan di kelas pertama pada tingkat SMA karena kebutuhan terhadap penguasaan materi ini diperlukan dalam berbagai bidang kehidupan. Berdasarkan uraian di atas, peneliti berinisiatif melakukan penelitian untuk mengembangkan suatu media pembelajaran komik matematika materi vektor dengan strategi PQ4R pada siswa SMAN I Langke Rembong. Harapannya, hasil penelitian ini dapat memberikan alternatif media pembelajaran bagi siswa, sehingga mampu meningkatkan prestasi belajarnya. 


\section{METODE}

Penelitian ini merupakan penelitian pengembangan. Penelitian pengembangan merupakan penelitian yang digunakan untuk mengembangkan atau menghasilkan produk atau meningkatkan keberadaan produk (Sugiyono, 2009). Produk yang diinvestigasi untuk dikembangkan adalah sebuah komik matematika yang dapat digunakan untuk membelajarkan materi vektor pada siswa SMA Kelas X.

Dalam penelitian ini penulis menggunakan model pengembangan ADDIE. ADDIE merupakan singkatan dari Analysis, Design, Development or Production, Implementation or Delivery, and Evaluation (Branch, 2009). Model ADDIE baik dikembangkan sebagai model pembelajaran yang inovatif karena memberikan proses belajar yang sistematis dan efektif dalam proses pembelajaran.

Populasi tidak dipilih dari seluruh siswa kelas X karena materi yang diteliti adalah materi vektor pada kelas matematika peminatan yang hanya diperoleh siswa pada kelas X Matematika dan Ilmu Alam (MIA) yang berkaitan dengan variabel penelitian. Karena keterbatasan dana, tenaga, dan waktu, dalam penelitian ini hanya mengambil sebagian dari populasi yang disebut sampel. Dalam penelitian ini, sampel yang diteliti adalah 36 orang yaitu 33,33\% dari populasi. Pemilihan sampel pada tahap ini dilakukan secara random kelas. Jumlah ini dipilih karena keterbatasan waktu dan dana untuk penelitian serta perbanyakan media komik yang akan digunakan dalam pembelajaran.

Penelitian dilaksanakan selama semester genap tahun ajaran 2017/2018 di SMAN I Langke Rembong. Dalam penelitian ini, ada tiga sumber data yaitu, (1) Validator, untuk mengetahui kelayakan dan kualitas komik matematika, (2) Guru, sebagai sumber data gambaran situasi pembelajaran, dan (3) Siswa, untuk mengetahui kepraktisan dan efek potensial komik matematika.

Instrumen dalam penelitian ini adalah lembar evaluasi komik, angket respon siswa, dan tes prestasi belajar siswa. Lembar evaluasi digunakan untuk memperoleh data kualitatif berupa penilaian komik matematika materi vektor dengan strategi PQ4R pada siswa SMAN I Langke Rembong tahun ajaran 2017/2018 oleh validator isi, validator bahasa, validator penyajian, grafika, dan guru. Tujuannya untuk keterbacaan visual komik matematika, memperoleh masukan dan perbaikan produk serta menentukan kelayakan komik matematika yang akan digunakan dalam implementasi di sekolah. Angket respon siswa digunakan sebagai alat untuk mencatat dan mengumpulkan data, mengenai respon siswa dalam suatu pembelajaran yang sudah berjalan atau sudah dilaksanakan. Angket respon siswa disusun untuk mengetahui seberapa besar respon siswa saat menggunakan komik matematika dalam pembelajaran. Tes prestasi belajar siswa yang digunakan untuk mengetahui sejauh mana efek potensial komik dalam proses pembelajaran. Tes yang digunakan berbentuk uraian. Teknik analisis data penelitian adalah, analisis data hasil lembar evaluasi, analisis data lembar hasil angket respon siswa, dan analisis data hasil belajar.

Data yang diperoleh dianalisis menggunakan formula berikut dan dilihat kriterianya seperti ditampilkan pada Tabel 1.

a. Analisis Data Hasil Lembar Evaluasi

Keterangan:

$$
\bar{X}=\frac{\sum x}{N}
$$

$\bar{X}=$ skor rata-rata

$\Sigma \mathrm{x}=$ jumlah skor

$\mathrm{N}=$ jumlah butir/subkomponen 
Formatif: Jurnal Ilmiah Pendidikan MIPA

Vol. 8, No. 3, Desember 2018, pp. 159-174

p-ISSN: 2088-351X

e-ISSN: 2502-5457

DOI: http://dx.doi.org/10.30998/formatif.v8i3.2716

Tabel 1. Kriteria Penilaian Validasi Ahli

\begin{tabular}{ccc}
\hline Komponen & Skor & Kriteria \\
\hline \multirow{2}{*}{ Isi } & $\bar{x} \geq 2,75$ & Lolos \\
& $\bar{x}<2,75$ & Lolos dengan revisi \\
& $\bar{x}=1$ & Tidak lolos \\
& $\bar{x}>2,50$ & Lolos \\
Kebahasaan & $\bar{x} \leq 2,50$ & Lolos dengan revisi \\
& $\bar{x}=1$ & Tidak lolos \\
Penyajian dan & $\bar{x}>2,50$ & Lolos \\
Grafika & $\bar{x} \leq 2,50$ & Lolos dengan revisi \\
& $\bar{x}=1$ & Tidak lolos \\
\hline
\end{tabular}

(BSNP, 2007: 21)

b. Analisis Data Lembar Hasil Angket Respon Siswa

Analisis angket respon siswa digunakan untuk menganalisis kepraktisan media pembelajaran komik. Pedoman penskoran pada angket respon siswa menggunakan kriteria penilaian yang disajikan pada Tabel 2 .

Tabel 2. Pedoman Penskoran Angket Respon

\begin{tabular}{lcc}
\hline \multirow{2}{*}{ Respon } & \multicolumn{2}{c}{ Skor Pernyataan } \\
\cline { 2 - 3 } & Positif & Negatif \\
\hline SS (Sangat Setuju) & 5 & 1 \\
S (Setuju) & 4 & 2 \\
KS (Kurang Setuju) & 3 & 3 \\
KS (Tidak Setuju) & 2 & 4 \\
STS (Sangat Tidak Setuju) & 1 & 5 \\
\hline
\end{tabular}

Rata-rata perolehan skor tiap aspek dan keseluruhan menggunakan rumus berikut.

Rata - rata skor tiap aspek $=\frac{1}{\text { banyak responden }} \times \frac{\sum_{\mathrm{i}}^{\mathrm{n}} \mathrm{x}}{\mathrm{n}}$

Rata - rata skor keseluruhan $=\frac{\text { jumlah } \mathrm{h} \text { rata }- \text { rata skor tiap aspek }}{\text { banyak aspek }}$

Keterangan:

$\sum_{i}^{n} x=$ jumlah perolehan skor tiap aspek

$\mathrm{n} \quad=$ banyak pernyataan tiap aspek

Selanjutnya, mengonversi skor rata-rata yang telah diperoleh menjadi kriteria kualitatif berdasarkan kriteria skala 5 sesuai Tabel 3 (Widoyoko, 2009).

Tabel 3. Kriteria Penilaian Perangkat Pembelajaran

\begin{tabular}{cl}
\hline Rentang Skor & Kriteria \\
\hline$X>4,2$ & Sangat Baik \\
$3,4<X \leq 4,2$ & Baik \\
$2,6<X \leq 3,4$ & Cukup \\
$1,8<X \leq 2,6$ & Kurang Baik \\
$X \leq 1,8$ & Sangat Kurang Baik \\
\hline
\end{tabular}


Formatif: Jurnal Ilmiah Pendidikan MIPA

Vol. 8, No. 3, Desember 2018, pp. 159-174

p-ISSN: 2088-351X

e-ISSN: 2502-5457

DOI: http://dx.doi.org/10.30998/formatif.v8i3.2716

c. Analisis Data Hasil Belajar

Tes hasil belajar siswa akan dianalisis untuk mengetahui efek potensial komik matematika yang dikembangkan. Nilai maksimum untuk tes ini adalah 100. Kriteria ketuntasan minimal yang digunakan oleh SMAN I Langke Rembong adalah 70. Kriteria ketuntasan ini dijadikan dasar untuk melihat efek potensial komik yang dikembangkan dengan pedoman seperti tampak pada Tabel 4.

Tabel 4. Pedoman Efek Potensial Komik

\begin{tabular}{cc}
\hline$\%$ Ketuntasan $(\mathrm{p})$ & Kriteria Efek Potensial \\
\hline $0 \leq p<41$ & Sangat Rendah \\
$41 \leq p<56$ & Rendah \\
$56 \leq p<66$ & Cukup \\
$66 \leq p<80$ & Tinggi \\
$80 \leq p<100$ & Sangat Tinggi \\
\hline & Sukardjo (Matutina, 2015)
\end{tabular}

Persentase ketuntasan dihitung dengan cara berikut:

$$
p=\frac{p_{1}}{p_{2}} \times 100 \%
$$

Keterangan:

$\mathrm{p}=$ persentase ketuntasan siswa

$p_{1}=$ jumlah siswa yang tuntas

$p_{2}=$ jumlah siswa keseluruhan

\section{HASIL DAN PEMBAHASAN}

\section{Tahap Analisis}

Hasil yang ditemukan pada tahap analisis adalah, (1) Proses analisis kebutuhan menunjukkan bahwa dibutuhkan strategi untuk meningkatkan minat dan motivasi belajar matematika sekaligus meningkatkan kemampuan dan prestasi belajar matematika. Strategi ini mengarah pada variasi penggunaan media dan strategi pembelajaran yang dapat mengakomodir semua siswa dengan beragam kemampuannya. (2) Proses analisis kurikulum meliputi kompetensi inti, kompetensi dasar, indikator pembelajaran materi vektor pada sub materi notasi dan operasi vektor beserta aktivitas pembelajarannya. (3) Proses analisis karakteristik menunjukan bahwa siswa telah berada pada tahap operasi formal menurut tahap perkembangan kognitif Piaget. Sebagian siwa telah dapat berpikir fleksibel dan efektif serta mampu berhadapan dengan persoalan yang kompleks, telah mampu memahami konsep-konsep abstrak meski ada berbagai konsep yang juga sulit mereka pahami. Oleh karena itu, dibutuhkan media pembelajaran yang meningkatkan pemahaman serta membuat pembelajaran menjadi menyenangkan.

\section{Tahap Desain}

Setelah peneliti melakukan berbagai analisis, tahap selanjutnya adalah membuat desain penelitian atau melakukan perancangan. Pada tahap ini peneliti melakukan perancangan yang meliputi, (1) Mengumpulkan bahan referensi yakni berupa buku maupun referensi dari internet dengan memperhatikan kesesuaian konten dengan komptensi inti, kompetensi dasar, dan indikator pembelajaran untuk dimasukkan sebagai konten komik matematika yang akan 
Formatif: Jurnal Ilmiah Pendidikan MIPA

Vol. 8, No. 3, Desember 2018, pp. 159-174

p-ISSN: 2088-351X

e-ISSN: 2502-5457

DOI: http://dx.doi.org/10.30998/formatif.v8i3.2716

dikembangkan. Selain buku-buku yang disebutkan, peneliti juga mengumpulkan berbagai clip art dari internet. Clip art ini digunakan untuk memperindah komik matematika sesuai dengan tahapan pembelajaran menurut strategi $\mathrm{PQ} 4 \mathrm{R}$ yang akan digunakan dalam pembelajaran di sekolah. (2) Menentukan judul komikdisesuaikan dengan tokoh dan alur cerita untuk membuat siswa penasaran dengan isi komik. Hal ini merujuk pada pendapat Tatalovic (2009) yang menyatakan bawa beberapa penelitian telah menekankan bahwa komik dan kartun animasi, adalah dua media yang paling populer secara tradisional dinikmati oleh orang muda yang mengandung referensi ke ide dan fakta ilmiah akurat. Judul komik matematika ini adalah "Ditris, Yanti, dan Vektor". (3) Penulisan alur secara garis besar, peneliti memilih jalan cerita yang sesuai dengan kehidupan remaja pada umumnya. (4) Komponen komik yang disesuaikan dengan tahapan PQ4R. (5) Merancang alat evaluasi meliputi yaitu lembar validasi ahli (ahli materi, bahasa, dan penyajian dan grafika), angket respon siswa, dan soal untuk tes prestasi belajar matematika untuk mengeahui kualitas dan efek potensial komik matematika materi vektor. Secara singkat, alur cerita komik matematika materi vektor adalah sebagai berikut.

Ditris, tokoh utama di dalam komik ini adalah seorang siswa kelas X di suatu SMA di kota. Ia mengalami perubahan di dalam dirinya sejak ia bertemu Yanti. Ditris, seorang anak yang cerdas namun malas dan nakal. Pertemuannya dengan Yanti, yang juga seorang siswi kelas $X$ di SMA yang sama menjadikan momen belajar sebagai bentuk pendekatan untuk suatu saat dapat memacari Yanti. Kecerdasan dan ketekunan Yanti dalam belajar membuatnya merasa tidak pantas menjadi pacar Yanti. Oleh karena, dengan tekun ia belajar demi mengimbangi kepintaran Yanti dalam bermatematika, ilmu yang juga menunjang pilihan jurusannya di perguruan tinggi kelak. Salah satu materi yang dipelajarinya adalah materi vektor pada sub materi notasi dan operasi vektor.

Sedangkan gambar dari isi halaman komik dapat ditunjukan pada Gambar 1.

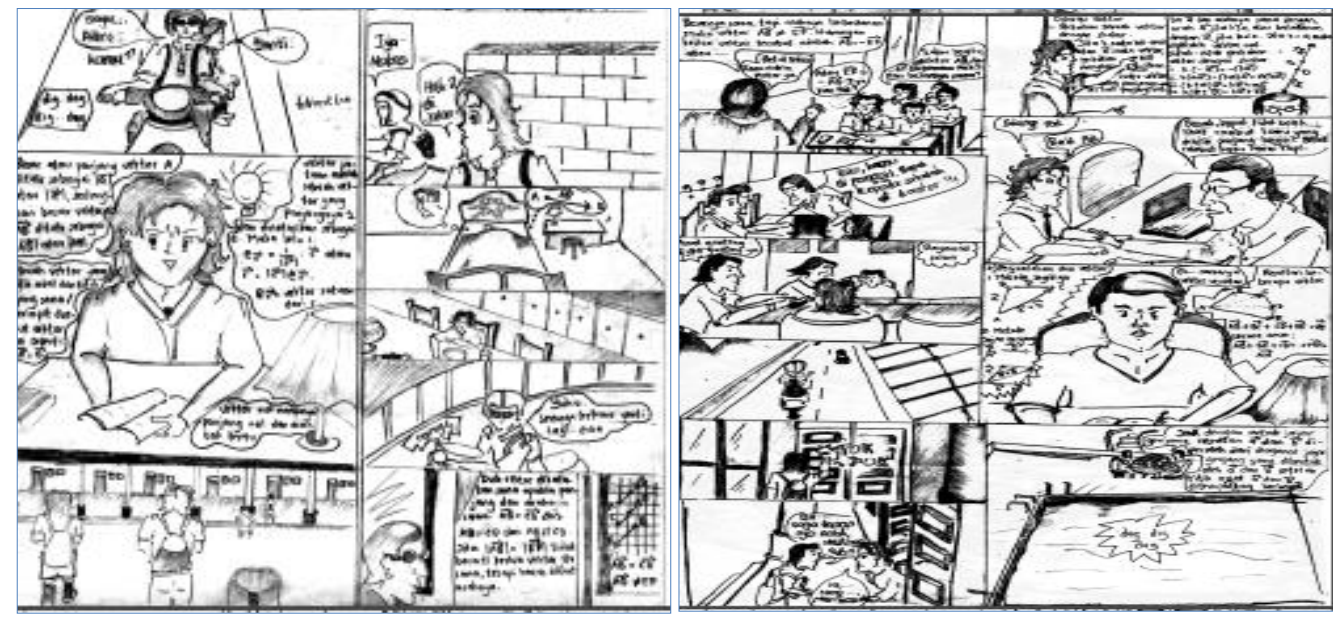

Gambar 1. Isi Komik

\section{Tahap Pengembangan}

Pengembangan komik matematika materi vektor dengan strategi Preview, Question, Read, Reflect, Recite, Review (PQ4R) dilakukan selama 2 minggu dengan rincian sebagai berikut, (1) Membuat plot (strukur rangkaian urutan dalam cerita, bagaimana bermula, apa inti cerita, dan siapa saja tokoh-tokoh di dalamnya), (2) Membuatdraft dengan pensil(Membuat outlite gambar, Menambahkan dialog). 
Setelah komik dibuat, komik divalidasi terlebih dahulu oleh para validator untuk mengetahui apakah komik yang dikembangkan layak atau tidak ataukah perlu diperbaiki sebelum digunakan sebagai media pembelajaran di dalam kelas. Komik divalidasi dari tiga segi yakni dari segi kelayakan isi (materi yang termuat di dalam komik), segi kelayakan bahasa, dan segi kelayakan penyajian dan grafika/multimedia.

Komik yang dikembangkan mengalami satu kali revisi berdasarkan saran dari validator penyajian dan grafika. Berdasarkan penilaian validator penyajian dan grafika, komik yang dikembangkan perlu diwarnai agar meningkatkan kesan menarik dari segi tampilan bagi siswa yang menggunakannya. Berikut disajikan tahapan revisi berdasarkan saran dan komentar validator penyajian dan grafika, seperti tampak pada Gambar 2.

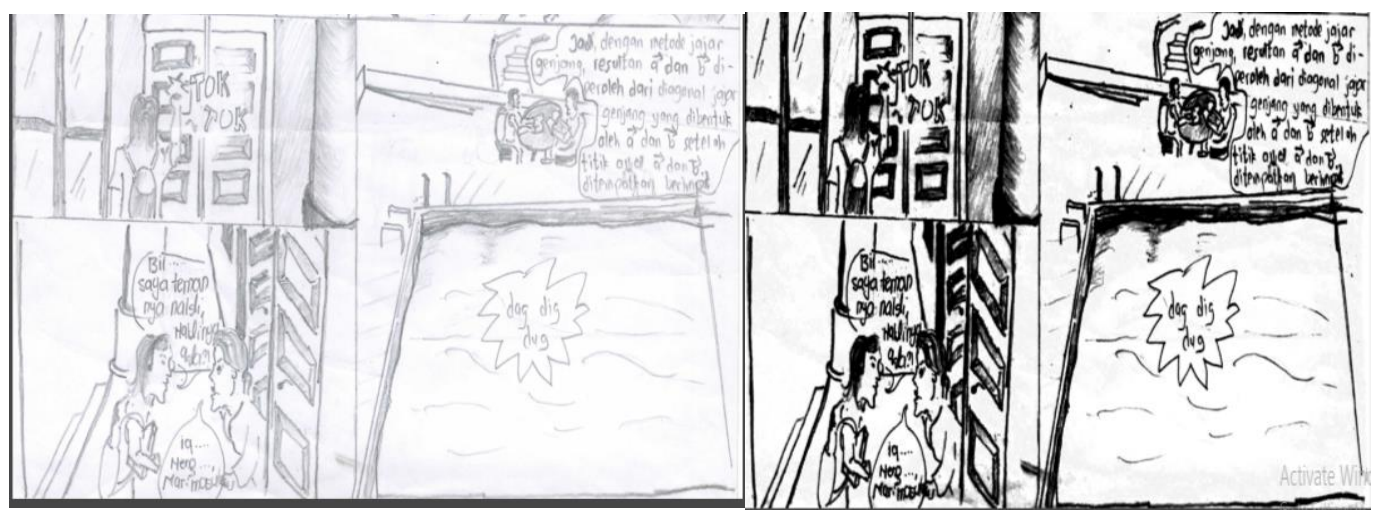

Gambar 2. Komik sebelum dan setelah revisi

Pemilihan warna dan pewarnaan juga perlu dilakukan dengan tepat dan teliti, agar keterbacaan visual komik menarik. Selain itu, perlu ditambahkan cover dengan judul komik beserta petunjuk penggunaan komik agar siswa yang menggunakannya tidak kebingungan dalam menentukan dialog mana yang perlu dibaca terlebih dahulu, yang mana yang akan dibaca setelahnya. Sementara penilaian dari validator materi dan validator bahasa menyatakan komik layak digunakan tanpa revisi.

\section{Tahap Implementasi}

Uji coba kecil dilakukan pada kelompok kecil sebelum komik digunakan pada skala yang lebih besar. Kelompok ini terdiri dari 6 orang siswa kelas X. Uji coba besar dilaksanakan setelah uji coba kecil selama dua minggu. Uji coba besar dilakukan pada siswa kelas X MIA1 SMAN I Langke Rembong. Tahap implementasi untuk uji coba kecil dan uji coba besar dilakukan dengan langkah-langkah sebagai berikut:

Preview: Secara singkat, peneliti memperkenalkan komik matematika materi vektor yang akan digunakan dalam pembelajaran dan siswa membaca ringkasan cerita komik pada lembaran preview. Ketika peneliti meminta siswa membaca selintas sinopsis yang disajikan di halaman preview, sebagian besar siswa telah mulai membaca isi komik. Ini menunjukkan bahwa siswa sangat antusias menggunakan media komik yang telah dikembangkan. Rasa ingin tahu mereka tumbuh dengan penggunaan media ini.

Question: Siswa membuat pertanyaan pada kartu pertanyaan berdasarkan tujuan pembelajaran untuk dijawab sendiri. Hasil pengamatan proses pembelajaran menunjukan bahwa sebagian besar siswa dengan aktif menulis pertanyaan yang berjumlah 4--6 nomor. Dari pertanyaan-pertanyaan yang diajukan ada tiga hal yang disimpulkan peneliti. Pertama, siswa memahami apa yang diminta yaitu membuat pertanyaan yang sesuai dengan tujuan pembelajaran. Kedua, ada beberapa siswa yang diakifkan/dibangun 
Formatif: Jurnal Ilmiah Pendidikan MIPA

Vol. 8, No. 3, Desember 2018, pp. 159-174

p-ISSN: 2088-351X

e-ISSN: 2502-5457

DOI: http://dx.doi.org/10.30998/formatif.v8i3.2716

keterampilan berpikir kritisnya dengan penggunaan media komik dengan strategi PQ4R ini. Hal ini terlihat daripertanyaan yang yang tidak terpikirkan oleh peneliti sebelumnya. Ini sangat menarik, karena pertanyaan yang diajukan masih berkaitan dengan materi pelajaran. Pertanyaan ini juga menantang peneliti untuk lebih mempersiapkan diri dengan baik. Ketiga, berdasarkan simpulan pertama dan kedua, dapat dilihat bahwa siswa sungguh aktif dalam mengikuti proses pembelajaran. Contoh hasil pada lembar question dapat ditunjukan melalui Gambar 3.
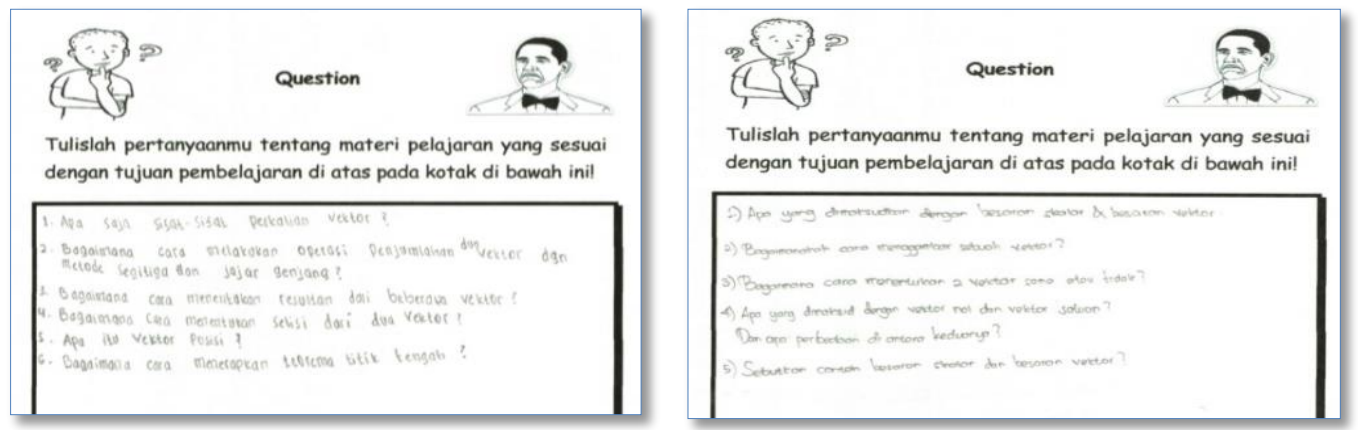

Gambar 3. Screenshoot tahap question

Read: Tahap ini memberi kesempatan kepada siswa untuk mengembangkan keterampilan bertanya. Hasilnya menunjukan bahwa siswa mampu membuat jawaban atas pertanyaan yang mereka ajukan sendiri. Setelah membaca komik secara lebih mendalam, sambil menikmati alur cerita, siswa terlihat mampu menemukan ide pokok serta menjawab pertanyaan yang telah dibuat pada tahap sebelumnya. Gambar 4 merupakan contoh salah satu hasil pekerjaan siswa pada tahap read.

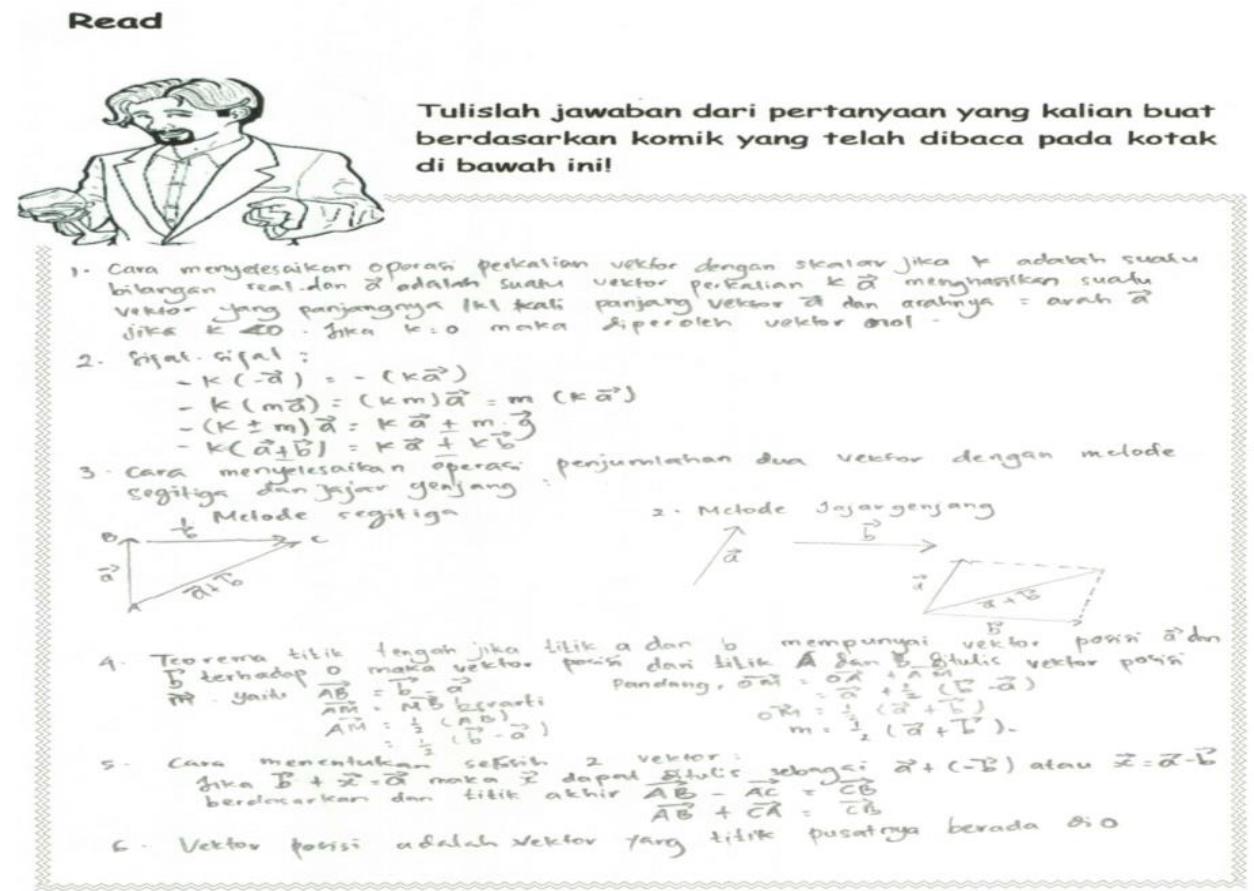

Gambar 4. Screenshoot Tahap Read 
Formatif: Jurnal Ilmiah Pendidikan MIPA

Vol. 8, No. 3, Desember 2018, pp. 159-174

p-ISSN: 2088-351X

e-ISSN: 2502-5457

DOI: http://dx.doi.org/10.30998/formatif.v8i3.2716

Reflect: Pada tahap ini, siswa mendengarkan penjelasan guru (peneliti) tentang materi pelajaran lalu membuat intisari dari penjelasan guru (peneliti). Hasilnya adalah siswa mampu mengerjakan beberapa contoh soal beserta pertanyaan atas pekerjaan tersebut.

Gambar 5 menunjukkan contoh salah satu lembar hasil pada tahap reflect.

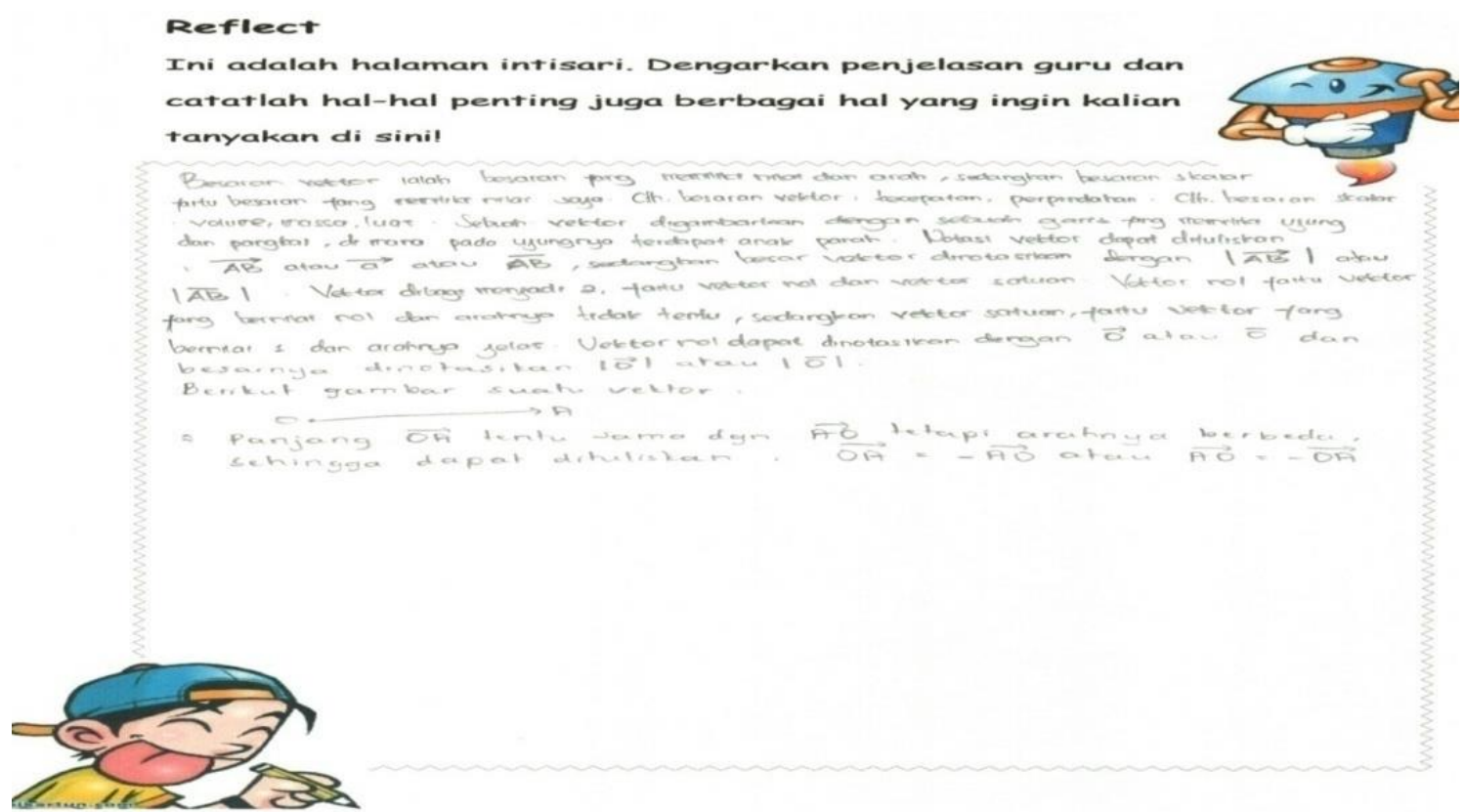

Gambar 5. Screenshoot Tahap Reflect

Recite: pada tahap ini peneliti memberikan LKS yang telah disatukan dengan komik, dikerjakan pada tahap ini untuk memperdalam pemahaman dan keterampilan menyelesaikan masalah yang berkaitan dengan vektor. Siswa juga mengajukan berbagai pertanyaan tentang materi pelajaran yang masih belum dimengerti seperti bertanya tentang cara penyelesaian soal pada lembar kerja siswa (LKS) yang sulit dikerjakan. Peneliti memberikan arahan untuk menolong siswa menemukan penyelesaian juga memberi kesempatan kepada siswa lain untuk menjawab pertanyaan yang diajukan temannya.

Review: Ini merupakan tahap terakhir dalam pembelajaran. Pada tahap ini, peneliti bersama peserta didik bersama-sama membuat simpulan secara lisan akan materi pelajaran yang telah dibahas bersama.

\section{Tahap Evaluasi}

Pada tahap ini peneliti mengevaluasi komik matematika yang telah dikembangkan untuk melihat kevalidan, kepraktisan, dan efek potensial komik matematika. Pertama, untuk mengetahui sejauh mana kevalidan komik matematika materi vektor, peneliti memberikan komik matematika kepada validator. Setiap aspek divalidasi oleh satu validator dan diberi skala 1 sampai 5 . Menurut penilaian validator, komik matematika yang dikembangkan baik. Selain itu, dapat digunakan dalam pembelajaran karena setiap aspek baik itu materi, bahasa, maupun penyajian, dan grafika memberikan nilai lebih dari 2,75. Nilai ini memenuhi kriteria penilaian media menurut Badan Standar Nasional Pendidikan (BSNP) yang dapat dilihat pada Tabel 1. Nilai kevalidan komik matematika materi vektor disajikan dalam Tabel 5. 
Formatif: Jurnal Ilmiah Pendidikan MIPA

Vol. 8, No. 3, Desember 2018, pp. 159-174

p-ISSN: 2088-351X

e-ISSN: 2502-5457

DOI: http://dx.doi.org/10.30998/formatif.v8i3.2716

Tabel 5. Nilai Kevalidan Komik Matematika dari 3 Aspek

\begin{tabular}{llll}
\hline No. & Aspek yang dinilai & Nilai kevalidan & Deskripsi Nilai \\
\hline 1. & Materi & 3,75 & Lolos \\
\hline 2. & Bahasa & 4 & Lolos \\
\hline 3. & Penyajian dan Grafika & 4 & Lolos \\
\hline
\end{tabular}

Kedua, untuk mengetahui kepraktisan media pembelajaran komik, peneliti menggunakan analisis angket respon siswa dan evaluasi komik matematika oleh guru. Pedoman penskoran pada angket respon siswa menggunakan kriteria penilaian yang disajikan pada tabel 2 sebelumnya yakni berupa Skala Likert dan diberi skor 1 sampai 5. Selanjutnya, mengonversi skor rata-rata yang telah diperoleh menjadi kriteria kualitatif.

Hasil penilaian angket respon siswa terhadap komik matematika materi vektor disajikan dalam Tabel 6.

Tabel 6. Hasil Angket Respon Siswa

\begin{tabular}{lllll}
\hline No & Implementasi & $\begin{array}{l}\text { Jumlah } \\
\text { Siswa }\end{array}$ & $\begin{array}{l}\text { Skor Angket } \\
\text { Respon Siswa }\end{array}$ & Kriteria \\
\hline 1 & Uji coba kecil & 6 orang & 4,47 & Sangat Baik \\
\hline 2 & Uji coba besar & 36 orang & 3,64 & Baik \\
\hline
\end{tabular}

Berdasarkan hasil angket respon, siswa menjadi lebih aktif dalam membangun pemahamannya sendiri dengan bertanya dan berdiskusi bersama teman dan guru. Hal ini dapat dilihat dari skor angket repon siswa baik dalam uji coba kecil maupun uji coba besar yaitu 4,47 dan 3,64 dengan kriteria baik dan sangat baik. Selain itu, masih terdapat beberapa siswa yang memiliki respon yang tidak baik terhadap komik matematika. Hal ini disebabkan oleh ketidaksukaan terhadap hal-hal yang berkaitan dengan matematika. Sedangkan hasil evaluasi komik matematika oleh guru memberikan skor 4,47 yang berarti komik lolos dan layak digunakan dalam pembelajaran.

Ketiga, berdasarkan hasil pekerjaan siswa pada tes prestasi belajar ditemukan bahwa pada uji coba kecil sebanyak 5 orang (dari siswa) yang mendapat nilai di atas KKM yaitu 70, sedangkan 1 orang mendapat nilai di bawah KKM. Sedangkan dalam uji coba besar, sebanyak 27 siswa memperoleh nilai di atas KKM (70) dan 9 siswa memperoleh nilai di bawah 70. Data analisis efek potensial komik matematika disajikan dalam Tabel 7.

Tabel 7. Hasil Analisis Efek Potensial Komik Matematika

\begin{tabular}{|l|c|c|}
\hline & $\%$ Ketuntasan & Kriteria Efek Potensial \\
\hline Uji Coba Kecil & $83,33 \%$ & Sangat tinggi \\
\hline Uji Coba Besar & $75 \%$ & Tinggi \\
\hline
\end{tabular}

Sepriyanti \& Tapia (2018) pada penelitiannya juga menyimpulkan bahwa penggunaan komik dalam pembelajaran matematika dapat mendukung proses pembelajaran yang efektif dan efisien sehingga prestasi belajar menjadi lebih baik. Di dalam pembelajaran matematika, siswa suka menggunakan komik matematika materi vektor. Komik juga membuat pembelajaran menjadi lebih menyenangkan. Ketika peneliti menyampaikan pembelajaran yang akan berlangsung menggunakan media komik matematika, siswa langsung bersorak gembira dan tertawa riang. Mereka senang, karena ini merupakan pengalaman pertama mereka melakukan pembelajaran dengan membaca komik di samping kesukaan mereka membaca berbagai komik non-Pelajaran. Siswa tidak 
Formatif: Jurnal Ilmiah Pendidikan MIPA

Vol. 8, No. 3, Desember 2018, pp. 159-174

p-ISSN: 2088-351X

e-ISSN: 2502-5457

DOI: http://dx.doi.org/10.30998/formatif.v8i3.2716

sabar untuk segera menyelesaikan membaca, melihat gambar-gambar dan dialog yang lucu yang membuat mereka tersenyum, dan tertawa.

Proses pembelajaran dilaksanakan melalui strategi PQ4R. Hal ini memungkinkan siswa membaca komik dengan melalui tahapan-tahapan tertentu. Ketika peneliti meminta siswa membaca selintas sinopsis yang disajikan di halaman preview, peneliti menemukan bahwa sebagian besar siswa melewati tahap itu dan sudah mulai membaca isi komik. Namun, peneliti tetap mengarahkan siswa untuk membaca komik secara bertahap sesuai dengan yang tertulis dalam setiap lembar tahapan dalam komik. Temuan ini menunjukkan bahwa siswa sangat antusias menggunakan media komik yang telah dikembangkan. Rasa ingin tahu mereka tumbuh dengan penggunaan media ini.

Pada tahap question peneliti meminta siswa membuat pertanyaan yang berkaitan dengan materi pelajaran pada pertemuan itu. Semua siswa membuat pertanyaan yang sesuai dengan tujuan pembelajaran. Ada juga siswa yang mengajukan pertanyaan di luar dugaan peneliti, seperti,

a. Siapakah yang mengemukakan konsep besaran skalar dan besaran vektor pertama kali?

b. Apakah besaran skalar bisa digambar karena hanya memiliki besar tanpa memiliki arah?

c. Mengapa vektor nol dikategorikan sebagai vektor?

d. Apa alasan digunakannya metode jajar genjang dalam penjumlahan dua vektor?

e. Apakah sifat asosiatif dapat terjadi pada penjumlahan dua vektor?

f. Dalam suatu koordinat cartesius bagaimana cara menentukan titik potong suatu vektor apabila menggunakan metode segitiga atau jajar genjang?

Pertanyaan-pertanyaan ini mengindikasikan akan kritis dan kreatifnya siswa ketika mereka diberi ruang untuk bertanya. Hal ini sangat jauh berbeda ketika guru menggunakan model pembelajaran langsung. Hanya ada beberapa siswa yang berani bertanya ataupun berkomentar. Dari berbagai pertanyaan yang muncul, peneliti juga memberi kesempatan kepada siswa yang mampu menjawab pertanyaan temannya. Sebagian besar siswa mengacungkan tangan, ingin menjawab pertanyaan-pertanyaan tersebut.

Berdasarkan angket respon siswa. siswa menjadi lebih aktif dalam membangun pemahamannya sendiri dengan bertanya dan berdiskusi bersama teman dan guru. Hal ini dapat dilihat dari skor angket repon siswa baik dalam uji coba kecil maupun uji coba besar yaitu 4,47 dan 3,64 dengan kriteria baik dan sangat baik. Meski begitu, masih ada beberapa siswa yang memiliki respon yang tidak baik terhadap komik matematika. Hal ini disebabkan oleh ketidaksukaan terhadap hal-hal yang berkaitan dengan matematika.

Penggunaan komik matematika dalam pembelajaran memberikan persentase $83 \%$ siswa lulus pada uji coba kecil dan $75 \%$ siswa lulus pada uji coba besar dalam tes prestasi belajar yang dilaksanakan pada pertemuan ketiga. Hal ini berarti efek potensial komik matematika pada uji coba kecil maupun uji coba besar masing-masing sangat tinggi dan tinggi. Berdasarkan wawancara dengan guru mata pelajaran matematika pada tahun sebelumnya, diperoleh informasi bahwa adanya peningkatan prestasi belajar matematika dalam pembelajaran dengan menggunakan komik matematika materi vektor. Pada tahun sebelumnya persentase ketuntasan siswa yang memenuhi KKM dari hasil ulangan pada subbab ini adalah 57,5\%, sedangkan setelah menggunakan media komik matematika, persentase ketuntasan belajar siswa menjadi $75 \%$.

Penilaian komik matematika materi vektor dari tiga aspek penilaian yaitu kevalidan (penilaian validator), kepraktisan (analisis angket respon siswa dan evaluasi komik 
matematika oleh guru, dan efek potensia (tes hasil belajar) memberikan nilai dengan kriteria BAIK dan LAYAK digunakan dalam pembelajaran.

Hasil penelitian di atas, sejalan dengan penelitian yang dilakukan oleh Devy Putri \& Ariyanti (2015) yang menyatakan bahwa berdasarkan angket tanggapan siswa dan hasil pretes, komik matematika telah memenuhi kriteria efektif, yaitu menarik, mudah dipahami dan terjadi peningkatan klasikal. Diperoleh siswa yang memenuhi KKM setelah pembelajaran adalah $77,14 \%$ dari jumlah siswa dalam satu kelas. Terjadi peningkatan sebesar $68,57 \%$ siswa yang memenuhi KKM setelah penggunaan media komik dalam pembelajaran. Selanjutnya, Hasanah (2016) menghasilkan kualitas komik dengan penilaian ahli materi yaitu $78 \%$ valid, oleh ahli desain media diperoleh $86 \%$ sangat valid, oleh guru bidang studi tematik $95 \%$ sangat valid, dan berdasarkan respon siswa diperoleh $80,60 \%$ valid. Secara umum kualitas komik yang dihasilkan adalah baik.

Kelemahan komik matematika yang telah dikembangkan ini terletak pada waktu yang dibutuhkan cukup lama dalam mengembangkannya dan partner yang bisa menggambar komik dengan baik dan menarik. Selain itu ada beberapa dialog dengan tulisan yang kurang jelas (ukuran huruf agak kecil).

\section{PENUTUP}

Media komik matematika materi vektor dengan strategi Preview, Question, Read, Reflect, Recite, Review (PQ4R) memiliki kriteria valid dari berbagai aspek komik dan kriteria sangat layak digunakan dalam kegiatan pembelajaran menurut validasi ahli materi dan ahli media. Selanjutnya, kepraktisan media yang dikembangkan masuk ke dalam kriteria lolos dan layak digunakan tanpa revisi. Terakhir, efek potensial komik matematika ini dikategorikan pada kriteria tinggi.

\section{DAFTAR PUSTAKA}

Abdullah, N. A., Shahrill, M., Yusof, J., \& Prahmana, R. C. I. (2018). Identifying the Factors Affecting Students' Performances in Primary School Mathematics. Journal of Physics: Conference Series, 1097(1), 012137.

Behzadi, M. H., Lotfi, F. H., \& Mahboudi, N. (2014). The study of teaching effective strategies on student's math achievements. Mathematics Education Trends and Research, 2014, 1-8.

Branch, R. M. (2009). Instructional Design: The ADDIE Approach (Vol. 722). Springer Science \& Business Media

Green, M. J., \& Myers, K. R. (2010). Graphic medicine: Use of comics in medical education and patient care. BMJ: British Medical Journal, 340, 574-577.

Hasanah, M. (2016). Pengembangan media pembelajaran matematika berupa comic book untuk meningkatkan hasil belajar siswa tematik materi jaring-jaring bangun ruang pada siswa kelas IV SD NU Bahrul Ulum Malang. Disertasi. Malang: Universitas Islam Negeri Maulana Malik Ibrahim.

Hendriana, H., Prahmana, R. C. I., \& Hidayat, W. (2018). Students'performance skills in creative mathematical reasoning. Infinity Journal, 7(2), 83-96.

Hosler, J., \& Boomer, K. B. (2011). Are comic books an effective way to engage nonmajors in learning and appreciating science?.CBE-Life Sciences Education, 10(3), 309-317. 
Jelatu, S., Mandur, K., Jundu, R., \& Kurniawan, Y. (2018). Relasi antara visualisasi spasial dan orientasi spasial terhadap pemahaman konsep geometri ruang. Journal of Songke Math, 1(1), 47-59.

Kleden, M.A., Kusumah, Y.S., \& Sumarmo, U. (2006). Analysis of enhancement of mathematical communication competency up on students of mathematics education study program through metacognitive learning. International Journal of Education and Research, 3(9), 349-358.

Makur, A. P., Prahmana, R. C. I., \& Gunur, B. (2018). Kemampuan berpikir tingkat tinggi, peserta osk matematika tingkat $\mathrm{SD}$, dan strategi think, talk, and write. Jurnal Pendidikan Matematika, 12(2), 23-32.

Marianthi, V., Boulodakis, M., \& Retalis, S. (2016). From digitised comic books to digital hypermedia comic books: their use in education. Piraeus: University of Piraeus.

Mudri, M. W. (2010). Kompetensi dan peranan guru dalam pembelajaran. Jurnal Falasifa, 1(1), 111-124.

Munandar, S.C.U. (2009). Pengembangan Kreativitas Anak Berbakat. Jakarta: PT Rineka Cipta.

Prahmana, R.C.I. (2013). Designing division operation learning in the mathematics of gasing. In Proceeding in The First South East Asia Design/Development Research (SEA-DR) Conference 2013 (pp. 391-398).

Prahmana, R.C.I. (2017). Design Research (Teori dan Implementasinya: Suatu Pengantar). Jakarta: Rajawali Press.

Putri, D. Y. K., \& Ariyanti, G. (2015). Pengembangan komik matematika sebagai media pembelajaran berbasis pendidikan karakter pada materi perkalian Bilangan Bulat Sekolah Dasar. Jurnal Ilmiah Edukasi Matematika (JIEM), 1(1), 22-38.

Ramdiah, S., \& Corebima, A. D. (2014). Learning strategy equalizing students' achievement, metacognitive, and critical thinking skills. American Journal of Educational Research, 2(8), 577-584.

Rasiman, R., \& Agnita, S. P. (2014). Development of mathematics learning media ecomic based on flip book maker to increase the critical thinking skill and character of junior high school students. International Journal of Education and Research, 2(11), 535-544.

Savitri, N. P. O., Arcana, I. N., \& Agung, A. G. (2013). Pengaruh strategi pembelajaran pq4r berbantuan media gambar terhadap hasil belajar IPS siswa kelas IV di SD Gugus VI Kecamatan Sawan. MIMBAR PGSD Undiksha, 1(1).

Sepriyanti, N., \& Tapia, C. (2018). The development of mathematics comics media on linear equations and linear inequalities of one variable. In SHS Web of Conferences (Vol. 42, p. 00115). EDP Sciences.

Sinurat, M., Syahputra, E., \& Rajagukguk, W. (2015). Pengembangan media pembelajaran matematika berbantuan program flash untuk meningkatkan kemampuan matematik siswa SMP. Jurnal Tabularasa, 12(02).

Stone, R. (2009). Cara-cara Terbaik Mengajarkan Matematika. Jakarta: Indeks.

Sugiyono. (2015). Metode Penelitian Pendidikan: Pendekaan Kuantitatif, Kualitatif, dan $R \& D$. Bandung: Alfabeta.

Sukmadinata, N. (2012). Pengembangan Kurikulum: Teori dan Praktek. Bandung: Remaja Rosdakarya.

Syam, A. (2016). Pengaruh persepsi tentang kualitas pelayanan sekolah, partisipasi dalam pembelajaran dan gaya belajar terhadap hasil belajar matematika. Daya Matematis: Jurnal Inovasi Pendidikan Matematika, 3(3), 290-298. 
Formatif: Jurnal Ilmiah Pendidikan MIPA

Vol. 8, No. 3, Desember 2018, pp. 159-174

p-ISSN: 2088-351X

e-ISSN: $2502-5457$

DOI: http://dx.doi.org/10.30998/formatif.v8i3.2716

Tatalovic, M. (2009). Science comics as tools for science education and communication: a brief, exploratory study. Jcom, 8(4), A02.

Wahyuningsih, A. N. (2012). Pengembangan media komik bergambar materi sistem saraf untuk pembelajaran yang menggunakan strategi PQ4R. Journal of Innovative Science Education, 1(1), 102-110.

Widodo, S. A. (2017). Development comic based problem solving in geometry. International Electronic Journal of Mathematics Education, 12(3), 233241.

Zulaekah, S., \& Hamida, K. (2012). Penyuluhan gizi dengan media komik untuk meningkatkan pengetahuan tentang keamanan makanan jajanan. KEMAS: Jurnal Kesehatan Masyarakat, 8(1), 67-73. 